\title{
Textual Agnogenesis and the Polysemy of the Reader: Early Modern European Readings of Qur’ānic Embryology
}

\author{
Pier Mattia Tommasino
}

Essi si sforzano estinguer la luce di Dio con le parole.

G.B. CASTRODARDO

\begin{abstract}
Being a bookworm need not always carry a negative connotation. We are reading creatures, we ingest words, we are made of words, we know that words are our means of being in the world, and it is through words that we identify our reality and by means of words that we are ourselves identified.
\end{abstract}

A. MANGUEL

Àgnosis

The sixteenth-century humanist Joseph Justus Scaliger once affirmed: 'I wish I were a good grammarian. Religious discord depends on nothing, except the ignorance of grammar (Utinam esse bonus grammaticus. Non aliunde discordiae

1 The research leading to these results has received funding from the European Research Council under the European Union's Seventh Framework Programme (FP7/2007-2013) ERC Grant Agreement number 323316, project CORPI 'Conversion, Overlapping Religiosities, Polemics, Interaction. Early Modern Iberia and Beyond'. The passages quoted at the beginning of this chapter were taken from L'Alcorano di Macometto (Venice: Arrivabene, 1547), fol. 48v, and Alberto Manguel, The Traveler, the Tower and the Worm (Philadelphia: University of Pennsylvania Press, 2013), p. 120. I would like to thank Lina Bolzoni, Jo Ann Cavallo, Stefano Gulizia, Seth Kimmel and Akash Kumar for the discussions we had while I was writing and re-writing this essay.

(C) PIER MATtia TOMMASINO, 2016 | DOI 10.1163/9789004324329_007

This is an open access chapter distributed under the terms of the CC-BY-NC-ND License. 
in religione pendent quam ab ignoratione grammaticae). Scaliger's dictum presents interesting solutions of interpretative problems. As far as I know, scholars have focused only on the rendering of the word grammatica, which was respectively understood as 'grammar', 'language', or in a broader sense as 'textual criticism', and 'textual interpretation'. Surprisingly, no interest has been shown for the rendering of the word ignoratio, 'ignorance.' ${ }^{2}$

Repertories of classical Latin distinguish ignoratio from ignorantia, giving to the first an active signification, 'the act of ignoring', and to the second both the active and passive signification, 'the lack of knowledge'. During the sixteenth century, ignoratio and ignorantia were substantially used as synonyms. Thus, in the context of Scaliger's dictum, ignoratio has been translated as 'absence of knowledge'. However, it could be also, and more interestingly, rendered with its active signification, as the 'act of ignoring something, or someone'. Accordingly, Scaliger's dictum seems to be based upon this ambiguity: religious discord depends both on the 'lack of knowledge' and on the conscious or unconscious 'act of ignoring' the grammatica of a revealed text. I would like to focus on ignoratio as a conscious and deliberate choice to ignore something, or someone.

\section{Gnārus}

Scaliger was writing during the second half of the sixteenth century, in the middle of the religious wars that shook Europe. As a good Calvinist, he essentially understood religion within the frame of the Mosaic distinction traced by Jan Assmann. Within this frame, religion means exclusive and revealed monotheism. Consequently, religious discord involves religious polemic about the interpretation of a revealed and written text. Further, religious polemic may arise within the boundaries of a specific monotheism such as Christianity, or between opposite and mutually exclusive monotheisms, namely Christianity and Islam. Polemicists assert the supremacy and uniqueness of one revelation, which could already present itself as a polemical text, such as the Qur'ān. In this case, polemicists deal with a text revealed in a foreign and ancient language, such as qurānic Arabic. Debating in a public dispute or, more frequently,

2 Jan Assmann, Of God and Gods, Egypt, Israel and the Rise of Monotheism (Madison: University of Wisconsin Press, 2008); Karla Mallette, Boustrophedon', in A Sea of Languages: Rethinking the Role of Arabic in Medieval Literary History, (ed.) Suzanne Conklin Akbari and Karla Mallette (Toronto: University of Toronto Press, 2013), pp. 254-66. 
writing a polemical treatise, polemicists could aknowledge the grammatica of the revelation, or they could deliberately ignore it.

Religious polemic, and particularly polemic based on translation, could then be described as a narrative of ignorance. The words narrator and narrative are derived from latin gnārus ('someone who knows', which can also be translated as 'skilful', 'practised' or 'expert'). Thus, the narrator is the 'one who knows' and 'who masters the story she or he is telling. By narrative of ignorance I mean a conscious discourse which creates ignorance (àgnosis) around a revealed text. In addition, the active ignoratio of the polemicist/translator (through misreading, misinterpretation, manipulation, philological forgery, falsification, and so on) finds its strength in the ignorantia of his audience. In general, an early modern audience of polemical treatises doesn't master the language of the revelation, but trusts the polemicist as gnärus 'expert' in the grammatica of the text to be refuted. Using this trust, the polemicist presents himself as the revealer of the true meaning of the revealed text. Even among Moriscos, and Ottoman Muslims along the Hungarian borders, the audience of public disputes and polemical treatises usually did not have knowledge of qurānic Arabic. ${ }^{3}$

According to this interpretation of Scaliger's dictum, the 'ignorance of grammatica' seems to overlap and occasionally match with the 'knowledge of grammatica. In fact, at least in the eyes of early modern scholars, both ignoratio and cognitio of grammatica have been the cause of religious discord. In 1608, a few months before Scaliger's death, the Italian poet Alessandro Tassoni, among preparatory materials for his miscellaneous work Dieci libri di pensieri diversi (Ten Books of Various Thoughts, 1620), wrote a long chapter about the relation between religion and grammatica. Tassoni states that religious discord depends on the knowledge of 'lettere' and 'dottrine'. Especially among heretics, schismatics, Jews and Muslims, textual criticism and textual interpretation can lead to religious conflict and to the fragmentation of the religious and political community. This is the case of Islam, for example:

Ora, la favolosa e la falsa [religione], le lettere e le dottrine l'hanno sempre guastata percioché hanno scoperto le favole e gli errori che sono in essa e, manifestandoli a' popoli, hanno fatto polular nuove sette, come fecero in Persia il Sofì, il Calife nel Cairo in Egitto, Elmael et Abdul Mumen in Marocco, Omar in Ea, Idris in Zaron, Chemid in Temesnà, lo Sciriffo nel Regno di Fessa, Elarit Ibnù nella città di Bagnaded e tant'altri che sotto

3 On gnārus see Valerio Magrelli, Che cosè la poesia (Bari: Laterza, 2005). On forgery and philology see Anthony Grafton, Forgers and Critics: Creativity and Duplicity in Western Scholarship (Princeton: Princeton University Press, 1990). 
nomi di sapienti e di riformatori e d'interpreti della legge maomettana hanno più volte turbata l'Africa e l'Asia. E però astutamente ordinò Maometto che non si disputasse la legge sua, ma che con la spada si difendesse. ${ }^{4}$

In the passage quoted above, which among other things reveals Tassoni's reading of Leo Africanus, Tassoni analyzed religious discord within Islam. He very pragmatically focused on the political unity of religion, arguing that 'letters' and 'doctrines' have always ruined religion, even 'false' and 'fabulous' religion. Muslim 'scholars', 'reformers' and 'interpreters of Muslim law', being able to 'discover and explain to people the errors' of Islam, contributed to spreading new sects and, accordingly, to the fragmentation of the umma (the community of believers). For this reason, 'Muhammad cleverly prohibited disputes about religion'. In Tassoni's opinion, knowledge of grammatica is a useful and dangerous tool. It is 'the bread knife' which could be used 'to slice a loaf or to kill a table companion': a murder weapon as sharp as Scaliger's ignorance of grammar.

\section{Tahrīf, Tafsīr}

Following the research of Hartmut Bobzin, Alastair Hamilton and Angelo Michele Piemontese, Thomas Burman has already keenly highlighted the ambivalence between polemic and philology in the translation of the Qurān in medieval and early modern Europe. He stressed the significant role of

4 Alessandro Tassoni, Pensieri e scritti preparatori, (ed.) Pietro Puliatti (Modena: Panini, 1986), 'Se per cagion della religione sien necessarie le lettere nella republica', ch. 189, pp. 341-43; 'Letters and Doctrines destroyed even fake religions. In fact, they unmasked their forgeries and theological mistakes. Also revealing their errors to the broad public, they helped the diffusion of new sects, such as the Sofi did in Persia, the Calife in Cairo, Elmael and Abdul Mumen in Marocco, Omar in Ea, Idris in Zaron, Chemid in Temesnà, the Sharif in the Reign of Fez, Elarit Ibnù in the city of Baghdad, and many others that under the name of wise-men, reformers and interpreters of Islam troubled Africa and Asia. Thus Muhammad was very cleaver when he prohibited to dispute his law, and ordered to protect it with the armies instead'. In the printed version of the Pensieri diversi the passage is slightly different. Muslim reformers and interpreters are less in number and they are placed next to Greek philosophers. See Tassoni, Dieci libri dipensieri diversi (Venice: Marc'Antonio Brogliollo, 1627), p. 335: 'Ora la falsa, e la favolosa, le lettere, e le dottrine l'hanno sempre guastata, havendo scoperte le favole, e gli errori che sono in essa, come già fecero Aristotile, e Socrate, ed altri Filosofi antichi, e manifestandogli a' popoli hanno fatto germogliar nuove sette, come in Persia il Sofì, il Fessa lo Sciriffo, in Babilonia Elarit Ebnù, Omar in Ea, Elmael in Marocco, e tant'altri che sotto nome di riformatori e sapienti hanno più volte turbata l'Africa e l'Asia'. 
philology beyond polemic, arguing that Latin 'translators have wittingly or unwittingly distorted the Qur'ān text so as to make it and Islam look silly or barbaric'. Burman also added that 'such tendentious translation is really rather rare' and that 'translators do make plenty of mistakes', which are 'overwhelmingly the mistakes of translators grappling honestly with the text'. Moreover, these mistakes are essentially the results of 'insufficient learning' and not of 'hostility' towards Islam. I will look at qurānic translations from a slightly different perspective. Focusing on qur'ānic embryology, I will analyse one of these 'mistakes', the creation of man out of a leech, and I will suggest that the 'insufficient learning' could be read both as ignorantia and ignoratio of the Qur'ān, and that the wittingness and un-wittingness of translators (Scaliger's boni grammatici), namely the act of 'manipulating the text' and the condition 'to be mistaken', could be both part of the same process of distortion of a revealed text. ${ }^{5}$

Of course, I do agree with the idea that any process of transmission of knowledge, especially based on translation, implies assimilation and refusal. In a recent study, I focused on the assimilation of qurānic episodes by early modern European trans-religious readers. For example, ordinary people such as the daring miller Menocchio, and the cheese-maker and prophet Scolio, shared with the Venetian rabbi Leon Modena the same qurānic readings, namely the Italian translation by Giovanni Battista Castrodardo (1547), to challenge Catholic worship of saints. In this brief essay, on the contrary, I am interested in analysing strategies of refusal of the Qurān, their internal mechanism and, in particular, their diffusion and reception among European readers. In other words, I want to focus on the European history of one specific polemical strategy, based on the misreading of qurannic embryology: the case of the the creation of man out of a leech. ${ }^{6}$

The elliptical and allusive style of the Qur'ann, as well as the polysemy of qurānic Arabic, permit Christian polemicists and Latin translators to play with the ignoratio, ignorantia and cognitio of its grammatica. Polysemy and pòlemos are closely tied. The polysemy of an ancient and revealed text, such as the Bible or in this case the Qurān, displays many possibilities of translation and makes the boundaries between misreading, manipulation and interpretation blurry. On this complexity, ideal for polemical and apologetical purposes, polemicists base their own power of revelation. Additionally, the ignorantia of the reader

5 Thomas Burman, Reading the Qur'än in Latin Christendom (Philadelphia: University of Pennsylvania Press, 2007), pp. 20-21.

6 Pier Mattia Tommasino, L'Alcorano di Macometto. Storia di un libro del Cinquecento europeo (Bologna: il Mulino, 2013); Harm den Boer and Tommasino, 'Reading the Qur'ān in the Seventeenth-Century Sephardi Community of Amsterdam', Al-Qanțara, 35 (2014):pp. 461-92; esp. pp. $477-81$. 
permits polemicists to present their ignoratio, tinged in turn with their own ignorantia, as a deep cognitio of the text. In other words, to use Arabic and Islamic categories, Christian polemicists present their tahrîf (manipulation, falsification) of the Qur'ān as the perfect tafsir (interpretation, commentary). This is evident in polemical texts, but also found, on a different scale, in medieval and early modern Latin translations of the Qur'ān, apparently self-promoting in prefaces and marginal notes as philological and non-polemical works. In these texts, ignoratio of grammatica, which following Richard N. Proctor we may define as textual agnogenesis, 'creation of ignorance aroud a text, and through a text', seems to be a hidden strategy, often or just occasionally displayed, to defuse and neutralize the revelation of the opponent. ${ }^{7}$

\section{Greek Leeches}

Focusing on the relation between the polemicist and his public suggests that knowledge and ignorance of revelation should be analyzed in terms of power relations. Polemicists used strategies of textual ignoratio, and linguistic and theological ignorantia, to seduce and persuade their audience. Among medieval and early modern European scholars of Arabic studies, ignoratio of grammatica, or textual agnogenesis, is a polemical and philological process, apparently overcome by a new 'scientific' approach developed by eighteenth and especially nineteenth-century scholars in Oriental languages. In 1705 the Dutch Orientalist Adriaan Reland published De religione Mohammedica libri duo (The two Books about the Religion of Muhammad), later described as 'the first scientific description of the institutions of Islam'. Ziad El-Marsafy, in his study on the Enlightment Qurān, illustrated the nature of Reland's work. Reland was actually concerned with demythologizing and correcting medieval and early modern Western views of Islam. The second part of the book lists and corrects numerous European misconceptions about the religion of Muhammad. Among several examples, Reland challenged the work of the twelfth-century Greek monk and polemicist Euthimios Zigabenos. Zigabenos claimed that Muslims believe that man was created out of a leech. In fact, chapter 36 of Reland's De Religione Mohammedica is dedicated to the creation

7 Richard Proctor, Agnotology: The Making and Unmaking of Ignorance (Stanford: Stanford University Press, 2008); see also Proctor, Race and Epistemologies of Ignorance (Albany: State University of New York Press, 2007); as well as Proctor, The Anthropology of Ignorance: An Ethnographic Approach (New York: Palgrave Macmillan, 2012). On polysemy in the Qur'ān see now Andrew Rippin, 'Al-Mubarrad (d. 285/898) and Polysemy in the Qur'ān', in Books and Written Culture of the Islamic World. Studies Presented to Claude Gilliot on the Occasion of His 75th Birthday (Leiden: Brill, 2015), pp. 56-70. 
of man. Using Muslim sources, Reland corrected the qur'ānic embryology forged by Zigabenos five centuries earlier. Reland wrote:

The Muslims say that man was created out of a leech (ex hirudine sive sanguisuga hominem fieri docent Mohammedani), if we trust Euthymius Zigabenos. Ek bdélles ánthropon gínestai légei, Muhammad said 'that the man was created out of a leech'. This error comes from the fact that the word 'alaq, that occurs in Koran 96, 2 - in which is written that 'man is created by God $\min$ 'alaq' - means piece of congealing blood (partem concreti sanguinem), and also leech (hirudinem). Consider also that 'aläqa, that sounds similar to the previous word, means semen (semen genitale). Hence, the Greeks (Graeculi), who were very quicked to slander the religion of Muhammad (in calumnias etvituperia religionis Mohammedicae nimis ingeniosi), supposedly confused these words (confuderunt haec vocabula). ${ }^{8}$

Reland referred to the first two verses of sura 96, the first chapter of the Qur'ān to be revealed to Muhammad. These verses are some of the many dealing with the creation of man and the formation of the embryo. Qurān 96,1-2 says as follows: '1 'iqrā bismi rabbika alladhì khalaqa / khalaqa al-insān min 'alaq' (' 1 Read in the name of your Lord, who created / 2 Created man out of 'alaq'). The words 'alaq (Qur'ān 96,2) and 'alaqa (Qur'ān 22,5; 23,14; 40,67; 75,38) are derivatives of the Arabic 'aliqa 'to cling', to adhere', 'to be attached to something'. Both forms of the word ('alaq and 'alaqa) refer in the Qur'ann to the second stage in the formation and development of the embryo, and, according to Galenic and Islamic embryology, have traditionally been translated as 'blood-clot', or 'piece of congealing blood'. Using commentaries on the Qurān by Muslim scholars (al-Jalālayn) and linguistic repertories of Arabic (al-Jawharī), Reland described Zigabenos' strategy as a deliberate act of textual agnogenesis. Reland explains that Zigabeno's strategy is essentially based on the polysemy of the word 'alaq, which could have been translated both with 'congealing blood' (sanguis crassus), and with the collective for 'leech' ('alaqa). ${ }^{\text {' }}$

8 Adriaan Reland, Hadriani Relandi de religione Muhammadica libri duo (Trajecti ad Rhenum: Gulielmi Broedelet, 1717), pp. 253-54; Ziad El-Marsafy, The Enlightement Qur'ān: The Politics of Translation and the Construction of Islam (Oxford: Oneworld, 2009), p. 19; Adel-Théodore Khoury, Polémique bizantine contre l'Islam (VIII ${ }^{e}-X I I I^{e} S$.) (Leiden: Brill, 1972), pp. 148-49.

9 Among the sources of Reland, see also the Thesaurus linguae Arabicae, translation of the al-Q̄ammūs by al-Fīrūzābādī, published by Antonio Giggei in Milano, 1632, s.v. al-'alaq 'Sanguis, Sanguis valde ruber, Sanguis crassior, Sanguis concretus'; al-'alaqa 'Pars huius- 
During the twelfth century, Zigabenos, possibly following the ninth century Nichetas of Byzantium, translated Arabic 'alaq with Greek $\beta \delta \varepsilon \dot{\varepsilon} \lambda \alpha$ 'leech', in order to prove the irrationality of the Qurān and in to attack Muhammad as an unqualified natural philosopher. Moreover, Reland underlined the choices the Latin translator could have had in the rendering of Arabic 'alaq. He distinguished classical Latin hirudo from vulgar Latin sanguisuga, the latter already attested in Plinius (Naturalis Historia, 8, 10). Regarding this distinction, in the second half of sixteenth century the Italian physician Ulisse Aldrovandi already wrote that the interpreters of the Septuaginta translated Hebrew 'aluqah (Proverbs 30, 15) with Greek $\beta \delta \dot{\varepsilon} \lambda \lambda \alpha$ 'leech', and Jerome with vulgar Latin sanguisuga (De animalibus, 7, 2 De hirudine). Among other details, such as the Italian regional synonyms of hirudo ('in Bologna we called it sanguettola, but in Rome and in Tuscany mignatta'), Aldovrandi pointed out the use of Arabic 'alaq among the old commentators of Avicenna (item alag apud veterem glossographum Avicenna)..$^{10}$

The two Latin renderings of Arabic 'alaq, classical Latin hirudo and vulgar, christian and medieval Latin sanguisuga, are helpful to describe the diffusion of medieval polemics in early modern Europe. This means that the history of language sheds light on the history of reading, permitting us to trace back the different lines of transmission of knowledge and ignorance about the Qur'ān throughout Europe. For instance, Pier Francesco Zini, the sixteenth-century Italian humanist who translated Zigabenos' works into Latin preferred hirudo to sanguisuga: 'Ex hirudine dicunt hominem fieri' (Panoplia Dogmatica, 1555). Four decades later, Zigabenos' Greek text was edited and translated into Latin by Friedrich Sylburg in Heidelberg. The passage was rendered as follows: 'Ex hirudine sive sanguisuga, hominem fieri docet' (Saracenica, sive Moamethica, 1595). Thus, Latin translations of Zigabenos' polemic circulated throughout Europe before Reland's philological readings, reaching seventeenth-century scholars such as Thomas Browne and Justus Lipsius. Both seem to have used the latter version (1595). Contemporary to Tassoni, and as worried as Tassoni about religious unity, Justus Lipsius in his Monita and exempla politica (1605) underlined that Muhammad's religion was based on superstition. Consequently, Muhammad was not just a pseudo-prophet but, more problematically, an unreliable ruler. Justus Lipsius described Muhammad's wonders through the

modi sanguinis'; al-'alaq 'Quidquid coagulator, Lutum in manu condensatum, et conglutinarum. Certamen. Dimicatio. (et e contra) Benevolentiae necessitudo, Amor'; al-'alaq $f i$ l-mä' 'Hirudo'; al-'alaqa 'Singularis hirudo'.

10 Ulisse Aldovrandi, De animalibus insectibus libri septem (Bologna: I.B. Bellagambam, 1602), book 7, ch.11, pp. 721-22. 
humanistic lens of Sylburg, reader and translator of Zigabenos: 'Hominem autem ex hirudine aut sanguisuga nasci. Quid addam?' What should Lipsius have added to this?11

\section{Spanish Worms}

Greek polemics and humanistic translations have not been the exclusive vehicles of textual agnogenesis about quraanic embryology. Since the beginning of the translation process of the Qurān into Latin in twelfth-century Spain, there were at least two different lines of translations of the term 'alaq, among Christian translators. In the Western Mediterranean, the term 'alaq was translated both as 'blood-clot' as well as 'leech'. The first translation dates back to Robert of Ketton and the Corpus islamolatinum (1143). Ketton translated the term 'alaq with coagulum sanguineum (blood-clot), and 'alaqa with coagulata massa (clotted lump). Through Robert of Ketton's Qur'ān, and other text of the Corpus, such as the Chronica mendosa et ridicula Saracenorum, this tradition reached an enormous number of European readers. This is the most traditional interpretation of the term, and it was actually based on quraanic commentaries, such as al-Ṭabarī and al-Zamakhsharī.

On the contrary, a second translation dates back to the Latin translation of the Qur'ān by Marcos de Toledo (1210). This text was not a polemical tract such as Zigabenos' treatise, but presents itself as a philological work, as a word by word (verbatim) translation of the Qur'an into Latin. In this text, indeed, the terms 'alaq and 'alaqa are translated into vulgar Latin sanguisuga. Qur'ān 96,12: '1 Confitere nomen Creatoris tui qui creavit, / 2 creavit enim hominem ex sanguisuga', (Confess the name of your Creator, who creates, / he creates the man out of a leech). The same happens in the rendering of Qurān 23,14: 'Deinde convertimus sperma (nutfa) in sanguissugam (thumma khalaqnā al-nutfata 'alaqa) et sanguissugam in carnem (mudgha); convertimus carnem

Euthymii Monachi Zigabeni Orthodoxae Fidei Dogmatica Panoplia, hucusque Latinis incognita, et nunc primum per Petrum Franciscum Zinum Veronensem e Graeco translata (Paris: Franciscum Barptolomaei Veneti, 1556), book 2, p. 24 ('Adversus Saracenos'); Saracenica, sive Moamethica, in quibus Ismaeliticae seu Moamethicae sectae praecipuorum dogmatum elenchus, ex Euthymii Zigabeni Panoplia Dogmatica (s.l.: H. Commelini, 1595), p. 31; Justus Lipsius, Monita et exempla politica libri duo (Amsterdam: G. Blaeuw, 1630), p. 25. On Lipsius and the Monita see Jan Papy, 'Fate and Rule, Destiny and Dynasty: Lipsius Final Views on Superstition, Fate and Divination in the Monita and Exempla Politica (1605)', in (Un) masking the Realities of Power: Justus Lipsius and the Dynamics of Political Writing, (ed.) Erik de Bom et al. (Leiden: Brill, 2011), pp. 195-206. 
in ossa ('izäman)', (Then we made the seed into a leech, and the leech into a lump of flesh: and then we made the lump of flesh into bones). ${ }^{12}$

This passage is particularly relevant because in another medieval work related to Marcos de Toledo, it is possible to find the same translation of the term 'alaqa taken from Qur'ān 23,14. Marcos de Toledo translated a series of short treatises by Ibn Tūmart (d. 524/1130), founder of the Almohads, who ruled the Maghreb and Spain in the eleventh and twelfth centuries. Among other works, Marcos de Toledo seems to have translated the Aqida (Creed) into the apologetic Tractatus Habentomi de unio dei (Treatise of Ibn Tūmart on the Unity of God). In this text, it is possible to read the same translation of the term 'alaqa. Distinctio 3, [4] states as follows: 'Deinde creavimus de ipso sanguisugam, carunculam quasi sanguinem congelatum, et de ipso sanguine quasi congelato ossa, et induimus ossa in carne, deinde ipsum creavimus hominem (Then we created out of that a leech, a little piece of flesh similar to congealing blood, and from this congealing blood we created the bones)'. Recently, Thomas Burman stated that the Aqìda by Ibn Tümart 'seems to have exercised very little influence in Latin thought about Islam'. Burman also added that 'we certainly have no knowledge currently of any readers of these Latin versions of Ibn Tūmart's short work.'13

I am less pessimistic than Thomas Burman. We do have knowledge of readers, copyists and even translators into vernacular languages of the Latin translation of the Aqïda. Recently, Travis Zadeh reminded us of the circulation of Ibn Tūmart's works, along with translations of the Qurān, among non-Arabic speaking Berbers of Morocco. In addition, and more interestingly, the Latin translation of the Aqida, and fragments of the Latin translation of the Qur'ān by Marcos de Toledo, as Luciano Formisano has demonstrated, circulated throughout Italy and were translated into Italian in Florence around 1460. After that, these Italian fragments were copied in Florence in the Vaglienti codex around 1514 (Florence, Biblioteca Riccardiana 1910). Ideologically opened by the text of Marco Polo, this codex contains an anthology of travel writings, as well as Vespucci's letters about the discovery of America and exotic curiosities about the Prester John. It was assembled between Florence and

Nàdia Petrus Pons, 'Alchoranus Latinus, quem transtulit Marcus canonicus Toletanus. Estudio y edición crítica' (PhD Diss., Universitat Autònoma de Barcelona, 2008), p. 411. The use of sanguisuga for 'alaq and 'alaqa is systematic in Marcos de Toledo. See also pp. 211, 303, 385 .

13 Thomas E. Burman, 'Libellus Habentometi de unio Dei', in Christian-Muslim Relations: A Bibliographical history, (ed.) David Thomas (Brill Online, 2014). I did not have time to look at the marginal notes to sura 96 by Ricoldo da Monte Croce in the Arabic Qurān he owned (Paris, Bibliothèque Nationale de France, Arabe 384). 
Pisa, after Florence conquered Pisa in 1509 and started planning to transform Porto Pisano into a new Tuscan terminal for Western Mediterranean and especially trans-Oceanic trade. The Italian translation of Ibn Tūmart says: 'Distinctio 3, [4] dipoi creamo di quello la sangusuga, la caruncula come sangue congelato, l'ossa, e l'ossa vestimo di carne'. (Then we created from that a leech, a little piece of flesh similar to congealing blood, and from this congealing blood we created the bones). ${ }^{14}$

Just a year after, in 1515, a polemical treatise, which became a European bestseller especially thanks to its Italian translation by Domingo de Gaztelu (1537), was published in Valencia. This book, is the Confusión o confutación de la secta Mahomética y del Alcorán by or attributed to the ex-Muslim scholar and convert to Christianity Juan Andrés from Xàtiva. In this text, the term 'alaq is not translated with hirudo or sanguisuga, but with gusanos 'worms.' The translator interpreted 'alaq as the plural of 'alaqa 'leech', but he seems to have intentionally used its hypernym 'worms'. Juan Vernet argued that Juan Andrés, being a convert and a polemicist, chose from among the possibilities he had the most derogatory meaning of the word 'alaq, that is 'leeches' and, afterwards, simplified 'leeches' into 'worms'. In the first chapter of the Confusión, within the frame of the biography of the prophet, Juan Andrés or the religious authorities behind him through their translation workshop, presented the first lines of the Qurān to be revealed to Muhammad, both in Arabic, transliterated into Latin alphabet, and in vernacular. Qur'ān 96: '1 O Mahoma, lee en nombre de tu Criador, / 2 el que crió el hombre de gusanos'. Moreover, if we read this passage along with Marcos de Toledo we can clearly retrace the line of transmission of this conscious, or unconscious, confusion of the text of the Qurann. Marcos de Toledo, in fact, as we already know, translated the Arabic 'alaq with sanguisuga and, interestingly enough, Rabbika 'your Lord' as Creatoris tui 'your Creator'. This is also the case in Juan Andrés' de tu Criador 'your Creator'. Both translated Arabic Rabb 'lord' as 'creator' (Arabic Khäliq). This second example is a textual counter-evidence of the diffusion of medieval Latin translations of the Qurān across Catholic and Morisco translation workshops. Moreover, if we compare Juan Andrés' rendering of 'alaq with the Spanish translation produced among Moriscos in 1609 for a Muslim audience, we can easily understand Juan Andrés' polemical strategy and the tradition of translation he followed. The text, edited by Consuelo López-Morillas, translates 'alaq (Qurān 96,2) as sangre espessa

14 Travis E. Zadeh, The Vernacular Qur'än: Translation and the Rise of Persian Exegeses (Oxford: Oxford University Press, 2012), pp. 126-27; Luciano Formisano (ed.), Iddio ci dia buon viaggio e guadagno. Firenze, Biblioteca Riccardiana, ms. 1910, Codice Vaglienti (Firenze: Polistampa, 2006), pp. 285-86. 
and 'alaqa (Qur'ān 23,14) as sangre, as the examples of Adriaan Reland (sanguis crassus) and Antonio Giggei (sanguis crassior) suggested a few decades later. $^{15}$

Recently, Mercedes García-Arenal and Katarzyna Starczewska have argued that behind the translation of the Qur'an by Egidio da Viterbo, and the translation workshop in Valencia that produced polemical tracts as the Confusión and the Lumbre de fe by Martín de Figuerola, there was essentially one translator, namely the Morisco Juan Gabriel de Teruel. Following this stimulating suggestion, we could find another Spanish-Italian connection for this story. The Latin Qurān sponsored by the cardinal Egidio da Viterbo (1518) translates 'alaqa into 'worm'. In the rendering of Qur'ān $96,1-3$, the second verse is actually omitted: ' 1 Lege nomen domini tui illius qui creavit! / 3 Lege per dominum tuum honoratum!' On the contrary, the rendering of Qur'ān 23,14 translates 'alaqa with vermis 'worm': 'postea creavimus sperma, vermem revivificatum, et creavimus in verme carnem, et creavimus in carne ossa', 'Then we create a seed, and then a revivified worm, and we created a lump in the worm, and we created the bones in the lump. ${ }^{16}$

Along with the Qurān by Marcos de Toledo, the Aqìda by Ibn Tümart, and the Qurān sponsored by Egidio da Viterbo, Juan Andrés' Confusión was also

15 Juan Andrés, Confusión o confutación de la secta Mahomética y del Alcorán,(ed.) Elisa Ruiz García and María Isabel García-Monge (Mérida: Editora Regional de Extremadura, 2003), p. 109. On Rabb as 'nourisher unto perfection', see Ali Akbar, God and Man: The Root of Creation and the Life Hereafter, the Holy Qur'ān and Modern Science (Leckwith: Seraj Publications, 1982), p. xxv.

16 Mercedes García-Arenal and Katarzyna K. Starczewska, 'The Law of Abraham the Catholic': Juan Gabriel as Qur'ān Translator for Martín de Figuerola and Egidio da Viterbo', Al-Qanțara, 35 (2014): pp. 410-56. Starczewska, 'Latin Translation of the Qur'ān (1518/1621) commissioned by Egidio da Viterbo. Critical Edition and Introductory Study', (PhD Diss., Universitat Autònoma de Barcelona, 2012), p. 345, see also p. 337. Another polemical text, produced in the same Spanish context, does not translate Qur'ān 96,2. See Lope de Obregón, Confutación del alcorán y secta mahometana, sacado de sus propios libros y de la vida del mesmo Mahoma (Granada: [n.p.], 1555), fol. 9v: 'O ya Muhemed acra bizmi rabige alledi halach halalça alinçine min halach acra bizmi rabique al-acran alledi allemebil çalam halleme alinçene melen yahlen. Que quiere dezir: 'O Mahoma, lee en el nombre del Criador el más honrado Señor, que enseño al hombre a escrevir con la pluma, lo que antes no sabía'. To understand the role of Augustinians in the diffusion of the Qurān in Humanistic Italy see Angelo M. Piemontese, 'Guglielmo Raimondo Moncada alla Corte di Urbino', in M. Guglielmo Raimondo Moncada alias Flavio Mitridate: un ebreo converso siciliano, (ed.) Mauro Perani (Palermo: Officina di Studi Medievali, 2008), pp. 151-71. 
read and copied in Italy during the sixteenth century. ${ }^{17}$ Moreover, through the Italian translation by Domingo de Gaztelu, printed in cheap and handy octavos throughout the sixteenth century, the worms by or attributed to Juan Andrés found many Italian and European readers. Gaztelu's translation states as follows: 'O Macomet, legi in nome d'il tuo Creatore, / quel che creò l'huomo de vermi'. Through the Italian printed translation of the Confusión, Juan Andrés' Spanish gusanos became vers in France, worme in England and, among other linguistic metamorphoses, were transformed again into the Latin vermes thanks to the pen of the German scholar Johann Lauterbach (1595).18

In 1595, the German Johann Lauterbach published his Latin version of Juan Andrés' Confusión, while the German Friedrich Sylburg was publishing his humanistic translation of Zigabenos' polemic. Both the Spanish and the Greek line of transmission of this episode of manipulated qurannic embryology, respectively represented by the Latin terms vermis and hirudo, passed through Italian translation workshops and the Italian printing press to reach a broader European readership. During the last decade of sixteenth century, the miller Menocchio could have been among the readers of Juan Andrés. Though this hypothesis is fascinating, it is very unlikely to be true. Using the metaphor of the cheese and worms, the miller Menocchio denied creationism, while in Juan Andrés, it is God who creates the man out of worms. Of course, we may imagine that Menocchio's creative memory could have mixed this passage of the Qur'ān, already manipulated by polemicists and translators, with the autoptic experience of fermentation, as well as with some confused and received ideas about the creatio ex nihilo. He could have, or he could have not. In addition, a contrastive analysis of Menocchio's reading of the Alcorano di Macometto by Giovanni Battista Castrodardo, printed by Andrea Arrivabene in 1547, demonstrated that Menocchio was a keen reader of the Qurān. He simply read the Qurān from another source. He understood and assimilated sections of the the text, using his cognitio of the grammatica of the Qur'ann to

17 Firenze, Biblioteca Medicea Laurenziana, Pluteo, book xLIV, ch. 38, fol. 9r: 'Et l'Angiolo disse: Leggi in nome del tuo creatore, il quale creò l'huomo di vermini'. On this manuscript, see Franco Bacchelli, 'Di Leone Africano e di una anonima Vita di Mahometto del sec. XvI', in L'Italia dell'Inquisitore. Storia e geografia dell'Italia del Cinquecento nella descrizione di Leandro Alberti, (ed.) M. Donattini (Bologna: Bologna University Press, 2008), pp. 231-46.

18 Juan Andrés, Italian translation by D. Gaztelu, Opera chiamata confusione della Setta Machumetana (Seville [Venice]: 1537), fol. 11v; J. Lauterbach, De bello contra Turcas suscipiendo. Commentatio Johannis Lauterbach in Noscovvitz Jurisconsulti confusio Sectae Mahometanae ab eodem Latinitate donata (Leipzig: Abraham Lamberg, 1595), p. 115: 'Angelus replicavit: O Mahomet, lege nomen tui creatoris, qui condidit hominem ex vermibus'. 
challenge Catholic worship of saints. In contrast, Justus Lipsius assimilated Zigabenos' confutation of qurānic embryology through humanistic Latin translations. He used Sylburg's version of Zigabenos' to challenge Muhammad as a pseudo-prophet and, consequently, as an unreliable ruler and lawgiver. These examples, and the different lines of diffusion of the translation of 'alaq, represented by hirudo, sanguisuga and vermis, lead us to reflect more generally about the reception and the readership of polemical works.

\section{European Readership, Possible Conclusions}

The history of this episode of confutation of the Qurān is useful to understand early modern European lines of the trasmission of knowledge and transmission of ignorance about Islam. Edward Said, commenting on Richard Southern's pioneering work, wrote that 'The best part of the book (Western views of Islam in the middle ages, 1962) is his demonstration that it is finally Western ignorance which becomes more refined and complex, not some body of positive Western knowledge which increases in size and accuracy. For fictions have their own logic and their own dialectic of growth or decline'. The current re-thinking of European Orientalism, beyond the Saidian discourse and the history of the representation of the other, is trying to demonstrate that 'refined ignorance' and 'knowledge' of Islam, whether positive or negative knowledge, are strictly interconnected during the medieval and early modern eras. 'Fictions' and 'forgeries', 'with their own logic and their own dialectic' actually stimulated the creation of 'knowledge of Islam' and Oriental languages. Thus, early modern Orientalism, along with and in the shade of humanistic Antiquarianism, played an active role in the transformation and development of the critical tools that were brought to bear in modern scholarship. For instance, facing the creation of man out of a leech, as an example of translatio ignorantiae, or even better of translatio ignorationis, Adriaan Reland turned to Islamic sources to correct Zigabenos' polemical reading of qurānic embryology. ${ }^{19}$

Along with the 'logic' and the 'dialectic' of 'ignorance', the lines of transmission of 'fiction' and 'forgeries' are also themselves revealing. Our example shows that focusing on the European corridors of translatio ignorationis allows us to describe and analyze the impact of Spanish Orientalism on Italian Renaissance culture, as well as the diffusion of hispano-arábica along with turcica in the European book market (for example Juan Andrés' Confusión and its translations). Early modern Spanish Orientalism, in fact, is particularly

19 Edward Said, Orientalism (New York: Random House, 2014), p. 62. 
interesting, because of its deep medieval Arabic-Latin roots, its overlap with the contemporary rewriting of the history of Spain, and its inescapable relation with the religious, cultural and linguistic issues of Morisco minorities. Moreover, Spanish Orientalism is currently engaging scholars, because its impact on the European and Mediterranean Republic of letters has not yet been systematically examined..$^{20}$

Following translatio ignorationis, it could also be possible to read the diffusion of Spanish Orientalism throughout Italy, under the light of its ideological counterpart: the reaction of Italian intellectuals to it, and the different ideological uses of Maurophilia and Hispanophobia in the formation of the national and regional identities of the Italian peninsula. At least since the early sixteenth century, up to the Risorgimento and then to the War of Spain, Italian intellectuals cyclically debated, refused and sometimes over-reacted against the revendication by Spanish scholars of the role Spain had in European intellectual history. A particular moment of this history is definitely the arrival of Spanish Jesuits to Italy, expelled in 1767 by Carlos III. This expulsion, and the debate raised in Italy among Spaniards and Italians about the supremacy of Spanish or Italian culture, is crucial to understand why the impact of Iberian Islam on Italy has never been properly studied. Still in 1936, for example, the entry Spain in the controversial Enciclopedia Italiana, referring to the activities of Spanish Jesuits in Italy during the late eighteenth century, states that: 'they [the Spanish Jesuits] confused art and science, poetry and thought, and they wrote no more than a history of culture [sic] with national and apologetical intentions. At least, however, they were able to underline the role of cultural mediator Spain had between East and West during the Middle Ages.. ${ }^{21}$

This episode of ignoratio of grammatica could lead instead to other conclusions and suggest different directions of research. It could be possible to

$20 \quad$ Pier Mattia Tommasino, 'The Qur’ān in Early Modern Iberia and Beyond', Al-Qanțara, 35 (2014): pp. 397-408.

21 Enciclopedia Italiana (Rome: Istituto dell'Enciclopedia Italiana Treccani, 1936), s.v. Spagna. On-line publication <http://www.treccani.it> [accessed March 2014]: 'I gesuiti, ma specialmente quelli che cacciati di patria trovarono rifugio in Italia (Esteban Arteaga, Juan Francisco Masdeu, Javier Lampillas), furono i più fervidi assertori del patrimonio spirituale della cultura spagnola. Essi la inserirono nel quadro generale della civiltà europea secondo quella linea di svolgimento e di progresso che era consona all'ideologia del tempo; ma tutti, qual più e qual meno, e in modo particolare Esteban Arteaga, Juan Francisco Masdeu, Javier Lampillas, confusero arte e scienza, poesia e pensiero, e fecero più che altro una storia della cultura con intenti apologetici nazionali. Comunque essi seppero mettere in rilievo la funzione mediatrice tra Occidente e Oriente esercitata dalla Spagna durante il Medioevo'. 
compare medieval and early modern textual agnogenesis with contemporary interpretation of the Qur'ān based on tafsir al-ilmi, tracing the path that brought qurānic embryology from being a topic of Latin medieval polemics to becoming the main battlefield for the apologies of the Qur'ann as a linguistic and scientific miracle. This choice could permit us to follow up on the analysis of ignoratio, ignorantia, and cognitio in commenting on the complex and slippery connections between science, revelation and textual interpretation in contemporary reading of the Qur'ān.

Since the early 1980 s, in fact, the spread of technique of reproductive medicine has led Muslim scholars to deal with new ethical problems, and to return to the interpetation of embryology in the Qurān, especially of the different stages of formation of the embryo in relation to the moment of the ensoulment. Accordingly to these new trends based on scientific observation of the embryo, the word 'alaq has no longer been translated exclusively as 'bloodclot', but as 'clinging, or hanging form', or metaphorically as 'leech-like clot', considering that between day 7 and day 24 the embryo clings to the endometrium of the uterus, in a similar way that a leech clings to the skin. This is the phase of the implantation of the embryo. This new metaphorical translation of the term 'alaq reflects the strategies of assimilation, negotiation, reconciliation, harmonization between science and revelation already analyzed by Marwa El-Shakri in her book on Reading Darwin in Arabic, 1860-1950. In contrast, Zigabenos' and Juan Andrés' readers used the literal interpretation, that is the literal misinterpretation of 'alaq, to emphasize the unreliable and superstitious irrationality of the same qur'annic vocabulary. ${ }^{22}$

\section{The Polysemy of the Reader}

Though I find these lines of research very promising, I would rather conclude this brief essay in a still different way. My rhetorical choice clearly reflects the statement of my conclusion: the description of the mechanism of a polemical project does not necessarily explain the causes of its diffusion or the reasons of its reception. Thus, I would not stress the passive and univocal reception of strategies of textual agnogenesis, nor their possible and positive outcomes in terms of philological and theological knowledge of a religious text. Instead, I would like to underline the independence of early modern readers. Even in

Marwa El-Shakri, Reading Darwin in Arabic, 1860-1950 (Chicago: University of Chicago Press, 2013). See also Maurice Bucaille, La Bible, le Coran et la science. Les écritures saintes examinees à la lumière des connaissance modernes (Paris: Seghers, 1976), pp. 200-06. 
the ages of classicism, readers could have deliberately refused to trust agnogenetists, or at least inadvertently neglected their textual strategies. The ongoing scholarly debate about the nature of Juan Andrés' text requires some methodological remarks regarding the study of its reception. It is very important to distinguish the construction of this polemical project, based on the exemplarly conversion to Christianity of the Muslim scholar Juan Andrés, from the great fortune of the text during more than three centuries. In other words, it is necessary to distinguish between the production of a text and its reception, or even better between the project and the projection of a text. In order to explain my point of view, I propose to use the reading practices of Baruch Spinoza. In his Tractatus Theologico-Politicus (1650), Spinoza observed:

It often happens that in different books we read histories in themselves similar, but which we judge very differently, according to the opinions we have formed of the authors. I remember once to have read in some book that a man named Orlando Furioso used to ride a kind of winged monster through the air, fly over any country he liked, kill unaided vast numbers of men and giants, and other such fancies which from the point of view of reason are obviously absurd. I read a very similar story, in Ovid, of Perseus, and also in the books of Judges and Kings, of Samson, who alone and unarmed killed thousands of men, and of Elijah, who flew through the air and at last went up to heaven in a chariot of fire, with fiery horses. All these stories are obviously alike, but we judge them very differently. The first one sought to amuse, the second had a political object, the third a religious one. ${ }^{23}$

This passage makes clear that Spinoza was not such a careful reader of Ariosto. Among other errors, his memory confused Orlando with Astolfo, a character that, on the contrary, Giordano Bruno chose as one of his literary alter-ego for his travels to the moon. Nevertheless, this passage of the Tractatus shows how

23 Baruch Spinoza, Tractatus Theologicus-Politicus (London: George Bell and Sons, 1887), p. 112, quoted in Alberto Manguel, A History of Reading (London: Penguin, 1996), p. 14. On the debate over Juan Andrés' text see Ryan Szpiech, Conversion and Narrative: Reading and Religious Authority in Medieval Polemic (Philadelphia: University of Pennsylvania Press, 2013); Szpiech, 'Preaching Paul to the Moriscos in the Confusión o confutación de la secta Mahomética y del Alcorán (1515) by Juan Andrés', La Corónica, 41 (2012): pp. 317-43; Jason Busic, 'Polemic and Hybridity in Early Modern Spain: Juan Andrés' Confusión o confutación de la secta Mahomética y del Alcorán',Journal of Early Modern Cultural Studies, 12 (2012): pp. 85-110. An interesting discussion of Szpiech's work is in the review of Seth Kimmel, Comparative Literature, 66 (2014): pp. 361-63. 
the diffusion of narratives of ascension could shed light on the reception of polemical works. Ten years after the translation of Juan Andrés into Italian (1537), Giovanni Battista Castrodardo used Juan Andrés' text to rewrite the biography of the prophet Muhammad, published in the introduction of his Alcorano di Macometto (1547). Castrodardo was neither interested in Juan Andrés' worms, nor in the polemical and personal frame traced by Juan Andrés or by the authorities behind the text attribuited to him. His eyes rested on other sections of the text. Being a commentator on Dante, Castrodardo discovered in Juan Andrés a new version of Muhammad's ascension to Heaven (mirrāj). Consequently, he read Muhammad's fabulous journey through the underworld and paradise, not as a fake miracle to be condemned, but as an enjoyable, beautiful and dantesque fiction. ${ }^{24}$

Contrary to Spinoza's model of reading, Castrodardo mixed literary entertainment with politics and religion. His Muhammad was Orlando/Astolfo, Perseus and Elijah at once. His reading of Juan Andrés, just as other many possible examples, suggests that describing the making of a polemical project does not necessarily explain its reception. As well as pòlemos and polysemy, polysemy and reception are closely tied too. Reception could actually be described as a continuing and in theory endless process of semantization of a text. If polemicists used the polysemy of a revealed text to create narratives of ignorance, readers of polemics in turn could have found new meanings to create their own personal narratives.

In Europe of the Old regime, in fact, religious polemics were neither exclusively read as polemical, nor just as religious. During the second half of the sixteenth century, for example, the Italian philologist Giovanni Maria Barbieri, cunningly or accidentally ignoring al-Kindī's arguments about qurānic rhetorics, used Ricoldo da Monte Croce, and the Qur'ān itself, to endorse the thesis of the Arabic origins of Romance poetry (1570). At the end of the eighteenth century, Girolamo Tiraboschi, the editor of Barbieri's work, in the middle of a fierce debate among Spanish and Italian Jesuits about Spanish Orientalism and the roots of European civilization, used Álvaro de Córdoba to endorse Barbieri's literary theories. Their reading of medieval polemics was apologetic. Literary and apologetic. Both Barbieri and Tiraboschi, in fact, brought religious polemics out of the frame of religion, just as Castrodardo's reading of Juan Andrés was focused on the fiction. Ironically, at the end the twentieth century,

24 On Giordano Bruno as a reader of Ariosto see Lina Bolzoni, Il lettore creativo. Percorsi cinquecenteschifra memoria, gioco, scrittura (Naples: Guida, 2012), pp. 59-82; Tommasino, L'Alcorano di Macometto, pp. 161-88. 
María Rosa Menocal read Álvaro de Córdoba retracing Girolamo Tiraboschi's path. ${ }^{25}$

Pòlemos and religio could or might not interest readers of religious polemic. In other words, narratives of conversion or narratives of ignorance were possible strategies of production of polemical texts, but they were and they are not the only lens through which we can read and analyze them. This means that Juan Andrés' worms didn't necessarily and univocally attract all the bookworms who opened his book. Those book-worms could have been boni or mali grammatici, observant readers or just careless, but free, persons who browsed the pages of his book looking for something else.

25 Giovanni Maria Barbieri, Dell'origine della poesia rimata, (ed.) Girolamo Tiraboschi (Modena: Presso la Società Tipografica, 1790), pp. 14-15, p. 42. María Rosa Menocal, The Ornament of the World:How Muslims, Jews and Christians Created a Culture of Tolerance in Medieval Spain (Boston: Little Brown, 2002), p. 66. Feliciano Delgado León, Álvaro de Córdoba y la polémica contra el Islam. El Indicus luminosus (Cordoba: Publicaciones Obra Social y Cultural Cajasur, 1996). 